\title{
From the Playhouse to the Courthouse: Indiana's NeEd For A STATUTORY Minimum Age FOR JUVENILE DELINQUENCY ADJUDICATION
}

\author{
TRAVIS WATSON
}

\section{INTRODUCTION}

How young is too young for a child to be arrested? How young is too young for a child to be placed in a juvenile detention facility? How young is too young for a child to be subject to the juvenile justice system or labeled a juvenile delinquent? These are questions states across the nation and countries around the world have been asking themselves for decades. ${ }^{1}$ Indiana is one of twenty-eight states that does not have a minimum age threshold that a child must meet in order for the juvenile justice system to have jurisdiction. ${ }^{2}$ Due to Indiana's lack of minimum age for juvenile court jurisdiction, a child under the age of eighteen, no matter how young, has the possibility of becoming a juvenile delinquent and may be subject to the juvenile justice system. ${ }^{3}$

Indiana's juvenile justice system once had a rehabilitative focus that looked out for the child's best interest and needs. ${ }^{4}$ Although the juvenile justice system's goal is to "ensure that children within the juvenile justice system are treated as persons in need of care, protection, treatment, and rehabilitation," there is now a more punitive approach. ${ }^{5}$ In Indiana, a juvenile delinquent is a child who "commits an act that would be an offense if committed by an adult." Because Indiana only defines an upper age jurisdictional limit of eighteen and no lower age limit establishing a minimum age for juvenile court jurisdiction, a child of any age under eighteen may be subject to Indiana's juvenile justice system. ${ }^{7}$ This

* J.D., Summa Cum Laude, 2020, Indiana University Robert H. McKinney School of Law; B.S. in Business, 2015, Indiana University Kelley School of Business. I would like to thank my family for their continued encouragement and support. I would also like to thank Professor Joel M. Schumm for his time, insight, and guidance throughout the Note writing process. My sincerest gratitude to MacKenzie Johnson, Riley Parr, and Amy Burbrink for their ideas, critique, and assistance in developing this Note.

1. See generally Elizabeth S. Barnert et al., Setting a Minimum Age for Juvenile Justice Jurisdiction in California, 31 InT'L. J. OF PRISONER HEALTH 1 (Mar. 13, 2017), https://www.ncbi. nlm.nih.gov/pmc/articles/PMC5841225/ [https://perma.cc/J63F-BJBL].

2. Minimum Age for Delinquency Adjudication-Multi-Jurisdiction Survey, NJDC, $\mathrm{http} / /$ njdc.info/practice-policy-resources/state-profiles/multi-jurisdiction-data/minimum-age-fordelinquency-adjudication-multi-jurisdiction-survey/ [https://perma.cc/YF6E-EKAE] (last updated Jan. 22, 2020).

3. See generally IND. CODE $\S 31-37-1-1$ (2019).

4. See Frank Sullivan, Jr., Indiana as a Forerunner in the Juvenile Court Movement, 30 InD. L. Rev. 279 (1997).

5. IND. CODE $\S 31-10-2-1(5)$ (2019).

6. IND. CoDE $\S 31-37-1-2$ (2019).

7. See generally $\S 31-37-1-1$. 
includes children who commit a delinquent act or even a status offense, such as truancy, running away from home, a fireworks violation, or even habitual disobedience of a parent or guardian. ${ }^{8}$ Further, a child who commits certain status offenses have the possibility of being placed in an Indiana's Department of Corrections detention facility. ${ }^{9}$

Twenty-two states, however, have laws that establish a minimum age for juvenile court jurisdiction to protect young children from the juvenile justice system. ${ }^{10}$ These lower limits are set by each state through statutes, and the minimum age limits span from six to twelve. ${ }^{11}$ In recent years, several states have proposed legislation to either raise the current minimum age or establish one. ${ }^{12}$ In 2018, Massachusetts raised its minimum age from seven to twelve. ${ }^{13}$ In 2019, California established its statutory minimum age at twelve. ${ }^{14}$

Indiana is no stranger to young children being arrested, processed through the juvenile justice system, and placed in a detention center. ${ }^{15}$ For example, a nineyear-old child with autism who was a victim of playground bullying tried to defend himself and consequently was handcuffed and arrested at his elementary school. ${ }^{16}$ This child was brought to the police station, charged with battery and criminal mischief, and detained briefly in the juvenile detention facility. ${ }^{17}$

In 2017, sixty of Indiana's ninety-two counties had 381 preliminary inquiries completed for children under the age of twelve and seven inquiries completed for children under the age of eight. ${ }^{18}$ These preliminary inquiries take place when a prosecuting attorney has reason to believe a child committed a delinquent act and the attorney instructs the intake officer to make a finding to determine whether or not the child should be charged. ${ }^{19}$ In addition, between October 1, 2017, and September 30, 2018, thirteen of Indiana's nineteen juvenile detention centers held

8. See $\$ 31-37-2-(2-7)$.

9. In re A.M.R., 741 N.E.2d 727, 729 (Ind. Ct. App. 2000) (holding a child could be placed in a detention center for being truant at school only after a court has ordered them to attend and they failed to do so).

10. Minimum Age for Delinquency Adjudication-Multi-Jurisdiction Survey, supra note 2.

11. Id.; MASS. GEN. LAws ch. 119, § 52 (2018).

12. See Mass. Gen. Laws ch. 119, § 52; see CAL. Welf. \& Inst. Code $\S 602$ (2019).

13. MASS. GEN. LAWS ch. $119, \S 52$.

14. CAl. Welf. \& Inst. Code $§ 602$.

15. Bulk data from the Indiana Office of Judicial Administration ("IOJA") is on file with the author.

16. Graham Hunter \& Audra Levy, 9-Year-Old Arrested and Handcuffed at Elementary School, THE INDY CHANnel (Oct. 30, 2017), https://www.theindychannel.com/news/localnews/johnson-county/9-year-old-arrested-and-handcuffed-at-elementary-school [https://perma.cc/BB24-HFV6].

17. $I d$.

18. Bulk data from the Indiana Office of Judicial Administration ("IOJA") is on file with the author.

19. IND. CoDE $\S 31-37-8-1$ (c) (2018). 
children between the ages of eight and eleven. ${ }^{20}$

Indiana is not the only state with cases involving young children in this context. ${ }^{21}$ Many other states without minimum age legislation process very young children into the state's juvenile justice system, often by arrest. ${ }^{22}$ Florida, like Indiana, does not have legislation specifying a minimum age for delinquency adjudication. ${ }^{23}$ In recent years, several young children have entered into Florida's juvenile justice system through arrests. ${ }^{24}$ This includes a group of second graders who were arrested for punching a boy while trying to steal his bicycle; a six-yearold child who was arrested for throwing rocks at cars; and a four-year-old, not yet in kindergarten, arrested with a group of children ages six, eight, nine, and eleven for felony burglary and misdemeanor criminal mischief for breaking into and vandalizing a neighbor's shed. ${ }^{25}$ These types of incidents might happen everywhere, but arrests and processing in the juvenile justice system happen in states that lack minimum age laws protecting young children. ${ }^{26}$

This Note argues that Indiana should pass statutory minimum age legislation that establishes a minimum age limit of twelve for a child to be adjudicated through Indiana's juvenile justice system. However, if the charge is that of a sexual ${ }^{27}$ or violent ${ }^{28}$ nature, then the minimum age should be lowered to ten. If a child under the minimum age commits what would be a delinquent act, then the case should be handled through a Child in Need of Services ("CHINS") proceeding. A CHINS proceeding would investigate both the parents and the child to determine the appropriate way to handle the case outside of the juvenile justice system. ${ }^{29}$ This will more appropriately carry out the intended purpose of the Indiana juvenile justice system to "ensure that children within the juvenile

20. See Legis. Servs. Agency, Fiscal Impact Statement HB1242 (2019), http://iga.in.gov/ legislative/2019/bills/house/1242\#document-354f0cc1.

21. See generally Tonya Alanez, The Youngest Kid Ever Arrested in Florida Was a 4-YearOld, Sun SENTINEL (Jan. 23, 2016), http://www.sun-sentinel.com/news/florida/fl-children-arrestedin-florida-20160122-story.html [https://perma.cc/YVD4-N64X].

22. See generally Travis M. Andrews, Six-Year-Old Handcuffed and Several Other Children Under Age 11 Arrested in Tennessee, Sparking Outrage, WASH. Post (Apr. 20, 2019), https://www. washingtonpost.com/news/morning-mix/wp/2016/04/20/six-year-old-handcuffed-and-several-otherchildren-under-age-11-arrested-in-tennessee-sparking-outrage/?noredirect $=$ on \&utm term=.5fa59dd785ad [https://perma.cc/XK6Z-4YWV]; see generally id.

23. Minimum Age for Delinquency Adjudication-Multi-Jurisdiction Survey, supra note 2.

24. Alanez, supra note 21.

25. Id.

26. See generally C.L.M. v. State, 874 N.E.2d. 386 (Ind. Ct. App. 2007).

27. IND. CODE $§ 35-42-4$ (2018).

28. IND. CODE $§ 5-2-6.1-8(1)$ (2019) ("Violent crimes" generally include crimes under the Indiana Code that are felonies or Class A misdemeanors that result in bodily injury or death to the victim.).

29. General Information About CHINS, Ind. Legal SERvices, InC., https://www. indianalegalservices.org/node/56/general-information-about-chins [https://perma.cc/CEW8-RAG2] (last visited Nov. 12, 2018). 
justice system are treated as persons in need of care, protection, treatment, and rehabilitation." ${ }^{30}$ Part I of this Note explains the history of the juvenile justice system and the changes it has undergone throughout the decades. Part II looks at states' upper age limits and states' lower age limits with further detail on the differing approaches to lower age limits. Part III argues why Indiana should have a statutory minimum age for a child to be subject to the juvenile justice system. Part IV proposes a solution for Indiana by establishing a statutory minimum age of juvenile court jurisdiction and expanding Indiana's CHINS statutes to allow for children under the jurisdictional minimum age who commit an offense to still receive the help and treatment they need.

\section{THE EVOLUTION OF THE JUVENILE JUSTICE SYSTEM}

The juvenile justice system has undergone many changes since its enactment. It started as informal and was vastly different than the adult system. However, after a series of United States Supreme Court cases, the juvenile court has transformed into a more adversarial system focused on due process and punishment, thus increasing the similarities to that of the adult system.

\section{A. Origins}

In the 1700s, noted eighteenth century jurist William Blackstone authored "Commentaries on the Laws of England," which identified people who were incapable of committing crimes. ${ }^{31} \mathrm{He}$ established that there are two elements that must be met in order for someone to be held accountable for a crime: There must be 1) a vicious will to commit the crime; and 2) an unlawful act committed. ${ }^{32}$ Blackstone identified children under the age of seven as "infants" who were unable to commit crimes because they did not have a "vicious will." 33 Teenagers over the age of fourteen were categorically considered adults and able to "suffer as adults" if found guilty of a crime. ${ }^{34}$ This led to a gray area for children between the ages of seven and fourteen.$^{35}$ If a child fell in this gray area, the presumption was that the child was incapable of the crime unless it appeared that the child knew between right and wrong. ${ }^{36}$ If the child did know the difference between right and wrong, they could "suffer the full consequences of the crime." 37

30. IND. CoDE $§ 31-10-2-1(5)$ (2019).

31. American Bar Association, The History of Juvenile Justice, ABA Division FOR PUBLIC EDUCATION, https://www.americanbar.org/content/dam/aba/migrated/publiced/features/DYJpart1. authcheckdam.pdf [https://perma.cc/8STG-8L7E] (last visited Sept. 28, 2018).

32. Id.

33. Id.

34. Id.

35. Id.

36. American Bar Association, The History of Juvenile Justice, ABA DIVISION FOR PUBLIC EDUCATION, https://www.americanbar.org/content/dam/aba/migrated/publiced/features/DYJpart1. authcheckdam.pdf [https://perma.cc/8STG-8L7E] (last visited Sept. 28, 2018).

37. Id. 
Prior to the 1899 enactment of the first United States juvenile court system, children were subject to the same criminal courts and punishments as adults. ${ }^{38}$ The courts sent children to the same jails as adults, where they were treated the same as adult offenders. ${ }^{39}$ Because of this, the common law rule was that children under the age of seven could not be guilty of a felony or punished for any capital offense. ${ }^{40}$ For children between the ages of seven and fourteen, the same presumption applied, but it was only "prima facie, and rebuttable." ${ }^{41}$ Many states in the 1800s had statutes that specified an age a child must reach before they could be held criminally responsible for their actions. ${ }^{42}$ For example, in Arkansas, the state statute provided that "an infant under twelve years of age shall not be found guilty of any crime or misdemeanor." ${ }^{.33}$ However, children were no longer eligible to use these protections once the juvenile justice system was established because they were now separated from the dangers of the adult system. ${ }^{44}$

A change in ideology that human behavior can be altered with rehabilitation led to the passing of the Illinois Juvenile Justice Act of 1899, which created the first United States juvenile court located in Cook County, Illinois. ${ }^{45}$ This juvenile court's goal was to treat juvenile offenders as children in need of aid, encouragement, and guidance instead of treating them like criminals. ${ }^{46}$ Those behind juvenile courts felt a child's brain and behavior were more likely to change compared to an adults, thus making it likely the child could be rehabilitated into a law-abiding citizen. ${ }^{47}$ Judge Julian Mack, one of the first judges to preside over the nation's first juvenile court stated:

The child who must be brought into court should, of course, be made to know that he is face to face with the power of the state, but he should at the same time, and more emphatically, be made to feel that he is the object of its care and solicitude. The ordinary trappings of the court-room are out of place in such hearings. The judge on a bench, looking down upon the boy standing at the bar, can never evoke a proper sympathetic spirit. Seated at the desk with the child at his side, where he can on occasion put his arm around his shoulder and drawl the lad to him, the judge, while losing none of his judicial dignity, will gain immensely in the effectiveness of his work. ${ }^{48}$

38. Juvenile Justice History, CTR. ON JUV. AND CRIM. JUST., http://www.cjcj.org/education1/ juvenile-justice-history.html [https://perma.cc/N4YW-M8HD] (last visited Sept. 28, 2018).

39. Id.

40. Allen v. United States, 150 U.S. 551, 558 (1893).

41. Id.

42. See id. at 558-59.

43. Id. at 558 (quoting Mansf. Dig. Ark. 1884, p. 425, c. 45, § 1498).

44. See The History of Juvenile Justice, supra note 31.

45. Marygold S. Melli, Juvenile Justice Reform in Context, 1996 Wis. L. REV. 375, 376.

46. Sullivan, Jr., supra note 4, at 282.

47. Melli, supra note 45 , at 377.

48. Julian W. Mack, The Juvenile Court, 23 HARV. L. REv. 104, 120 (1909). 
The original juvenile court differed significantly from adult courts, where due process is of great importance and proportionate retribution is the goal..$^{49}$ In 1903 , Indiana established one of the first juvenile courts in the United States ${ }^{50}$ and by 1925 , all but two states established some type of juvenile court system. ${ }^{51}$ By 1945 , every state had a juvenile justice system. ${ }^{52}$ Early juvenile courts were based on the parens patriae doctrine, which gives the state power to serve as a parent figure to juveniles with legal troubles and imposes the ultimate goal of leading them to be law-abiding, responsible adults. ${ }^{53}$ The doctrine allows juvenile courts to act in the "best interest of the child" focusing on aid, encouragement, and guidance by emphasizing an informal, non-adversarial approach. ${ }^{54}$ However, due to a change in ideology and a series of United States Supreme Court decisions in the last half century, juvenile courts now follow a more adversarial approach. ${ }^{55}$

\section{B. The Due Process Years: Breakdown of Parens Patriae}

The United States' juvenile justice system has undergone many changes since its inception in $1899 .{ }^{56}$ Public concern regarding the juvenile courts' ability to act fairly began to grow in the 1950s because juvenile judges acted with a high degree of discretion as to how they chose to handle cases. ${ }^{57}$ The increased amount of mistreatment of children in the juvenile justice system also became a prominent public concern at this time. ${ }^{58}$ In response to this concern, the United States Supreme Court decided a series of juvenile cases in the 1960s that recognized the shift in the juvenile justice system from the original parens patriae system to a system focused on punishment. ${ }^{59}$

In 1966, the Supreme Court ruled in its first juvenile case: Kent v. United States.$^{60}$ Kent recognized that juvenile courts acted more as courts and less as a parent figure. ${ }^{61}$ The Court found a need to enact protections for juveniles. ${ }^{62}$ The Court further recognized that juvenile courts had great latitude concerning

49. Jeffery A. Butts \& Ojmarrh Mitchell, Brick by Brick: Dismantling the Border Between Juvenile and Adult Justice, National Criminal Justice Reference Service, 2000, at 168, https://www.ncjrs.gov/criminal_justice2000/vol_2/02f2.pdf [https://perma.cc/6YPT-9YZR].

50. Sullivan, Jr., supra note 4, at 279.

51. Susan A. Burns, Is Ohio Juvenile System Still Serving Its Purpose?, 29 AKron L. Rev. 335, 337 (1996).

52. Id.

53. The History of Juvenile Justice, supra note 31.

54. Id.

55. See id.

56. See Melli, supra note 45.

57. Juvenile Justice History, supra note 38.

58. Id.

59. Id.

60. Kent v. U.S., 383 U.S. 541, 555-56 (1966).

61. See Burns, supra note 51, at 340-41.

62. Id. at 341 . 
discretion over juveniles, but they should not have a "license for arbitrary procedure." ${ }^{63}$ It held that juveniles should receive some of the same due process protections that adults do: the right to a meaningful hearing and the right to counsel. ${ }^{64}$ Justice Abe Fortas had concerns about fairness and the direction the juvenile court system was heading:

While there can be no doubt of the original laudable purpose of juvenile courts, studies and critiques in recent years raise serious questions as to whether actual performance measures well enough against theoretical purpose to make tolerable the immunity of the process from the reach of constitutional guarantees applicable to adults ... [T] here may be grounds for concern that the child receives the worst of both worlds: that he gets neither the protections accorded to adults nor the solicitous care and regenerative treatment postulated for children. ${ }^{65}$

A year later, In re Gault continued the trend of expanding juveniles' rights. ${ }^{66}$ The Supreme Court held the Constitutional rights provided to adults should extend to children in juvenile courts. ${ }^{67}$ Juveniles should have the right to notice, counsel, confrontation of witnesses, and cross examination. ${ }^{68}$ This decision further blurred the lines between juvenile courts and adult courts; however, the Court recognized that this holding would drastically alter the juvenile justice system without destroying it. ${ }^{69}$ In Justice Black's concurring opinion, he stated that "[t]his holding strikes a well-nigh fatal blow to much that is unique about the juvenile courts in the Nation."

By 1970, in In re Winship, the Supreme Court held that the courts must use a "beyond a reasonable doubt" standard when juveniles are charged with a criminal act. ${ }^{71}$ Although the Court, again, said its decision would not "dismantle the juvenile system's philosophy," it did further change the juvenile court judge's role to that of a judge and less as a parent. ${ }^{72}$

63. $I d$.

64. Id. at 347.

65. Kent, 383 U.S. at 555-56.

66. Burns, supra note 51, at 342-43.

67. In re Gault, 387 U.S. 1, 10 (1967).

68. Id.

69. Id. at 21 (noting that "the observance of due process standards, intelligently and not ruthlessly administered, will not compel the States to abandon or displace any of the substantive benefits of the juvenile process."). If this holding did not totally change the juvenile justice system, it at least clouded the distinctions between it and the adult system.

70. Id. at 60 (Black, J., concurring).

71. In re Winship, 397 U.S. 358, 368 (1970).

72. Burns, supra note 51, at 345. The Court further held in Breed v. Jones that the adult double jeopardy standard extended to juveniles. 421 U.S. 519, 525 (1975). However, in McKeiver v. Pennsylvania, the Court marked a departure from this current trend of giving juveniles the same protections as adults. 403 U.S. 528 (1971). The Court held that juveniles did not have a right to trial by jury in any juvenile proceedings. $I d$. at 545 . 
The 1980s carried a perception that the juvenile justice system was too lenient. ${ }^{73}$ In response, many states started a "tough on crime" approach. ${ }^{74}$ This lead to record levels of juveniles in the system and influenced some states to adopt additional protections for juveniles-including upper and lower age limits. ${ }^{75}$

Juvenile courts originally placed great importance on making juveniles feel they were in the court's "care and solicitude" during informal hearings. ${ }^{76}$ However, as public concern grew about the fairness of the system, juvenile courts have shifted away from its original intended purpose to a system focused on punishment, blurring the lines between adult and juvenile courts. ${ }^{77}$ Due to this, several states now have legislation to protect children and offset the growing similarities between adult and juvenile courts. ${ }^{78}$

\section{STATE JURISDICTIONAL BOUNDARIES FOR JUVENILE COURT JURISDICTION}

Although states generally follow a consistent approach with upper age limits for juvenile court jurisdiction, they take a variety of approaches in regard to lower age limits. Of the states that do have lower age limits, they differ on the statutory minimum age, how the law is written, and how to hold children responsible for the laws they break.

\section{A. States’ Upper Age Limits}

Every state, including Indiana, ${ }^{79}$ has an upper age limit that defines the age at which juvenile courts no longer have jurisdiction over a juvenile. ${ }^{80}$ In the majority of states, juvenile courts no longer have jurisdiction over a person once they turn eighteen.$^{81}$ In nine states, juvenile courts lose jurisdiction when a person becomes seventeen. ${ }^{82}$ However, two of these states have legislation to raise the upper age limit to eighteen, further protecting children from the dangers of adult courts. $^{83}$

73. Juvenile Justice History, supra note 38.

74. Id.

75. Id.

76. Mack, supra note 48.

77. Juvenile Justice History, supra note 38.

78. See Angel Zang, U.S. Age Boundaries of Delinquency 2016, JuveniLe JustiCe Geography, Policy, Practice \& Statistics (July 2017), http://www.ncjj.org/pdf/JJGPS\% 20StateScan/JJGPS_U.S._age_boundaries_of_delinquency_2016.pdf [https://perma.cc/K89WCXEH]; see Minimum Age for Delinquency Adjudication-Multi-Jurisdiction Survey, supra note 2.

79. See Ind. CodE $§ 31-37-1-2$ (2018).

80. Zang, supra note 78.

81. Id.

82. Id.

83. Id. 
Moreover, the Federal Juvenile Delinquency $\mathrm{Act}^{84}$ defines juvenile delinquency as "the violation of a law of the United States committed by a person prior to his eighteenth birthday which would have been a crime if committed by an adult." ${ }^{85}$ All states and the United States federal government recognize a need to protect juveniles from the dangers of adult court and have enacted laws defining an upper age jurisdictional limit creating a separation between adult court and juvenile court jurisdiction. ${ }^{86}$

\section{B. States' Lower Age Limits}

Indiana affords juveniles many additional protections beyond the United States Constitution's baseline protections including additional protections against searches and seizure, interrogations and statements to police, Miranda warnings, and statutory age limits on waiver to adult court. ${ }^{87}$ However, unlike twenty-one other states and territories, Indiana does not have statutory protections defining the minimum age a child must reach in order to be adjudicated in Indiana's juvenile justice system. ${ }^{88}$ In theory, any child committing a crime in Indiana, no matter how young, could be arrested, processed through the juvenile justice system, and sentenced to serve time in a detention facility. ${ }^{89}$ Unlike upper age limits, there is no consistency when it comes to states' minimum age laws. ${ }^{90}$ Because of juvenile courts shifting to resemble adult courts, states have passed legislation to offer protections for young children by not allowing them to be subject to the juvenile justice system's jurisdiction. ${ }^{91}$

States that have minimum age legislation take different approaches to how laws are written and enforced..$^{2}$ Most states simply have an absolute bar on juvenile jurisdiction based on age alone. ${ }^{93}$ Along with an absolute bar, other states

84. 18 U.S.C. $\S 5031(2018)$.

85. Id.

86. Zang, supra note 78.

87. See Frank Sullivan, Jr., A Look Back: Developing Indiana Law Post-Bench Reflections of an Indiana Supreme Court Justice Selected Developments in Indiana Juvenile Justice Law (1993-2012), 48 IND. L. REV. 1541 (2015).

88. Id.

89. See Ind. CodE $§ 31-37-1-1$ (2018).

90. Fourteen states have a statutory minimum age set at ten, Connecticut and New York have a statutory minimum age set at seven, California and Massachusetts have a statutory minimum age set at twelve, Nebraska has its statutory minimum age set at eleven, Washington has its statutory minimum age set at eight, North Carolina has its statutory minimum age set at 6, and Minnesota has a common law minimum age for juvenile delinquency proceedings set at ten. See Minimum Age for Delinquency Adjudication-Multi-Jurisdiction Survey, supra note 2.

91. Id.

92. See generally id.; see 42 Pa. Cons. Stat. § 6302 (2018); see MASs. Gen. Laws ch. 119, $\S 52$ (2018); see N.C. GEN. STAT. § 7B-1501(7) (2018).

93. See generally Minimum Age for Delinquency Adjudication-Multi-Jurisdiction Survey, supra note 2; 42 PA. CONS. STAT. § 6302 (2018); MASs. GEN. LAWS ch. 119, § 52 (2018); N.C. 
provide for an age range that allows for a rebuttable presumption to be used to show the child did not have the mental culpability to commit the crime. ${ }^{94}$ Additionally, some states provide programs outside of the juvenile justice system that a child must participate in if he or she has committed a crime but is too young to enter into the juvenile justice system. ${ }^{95}$ All of these approaches offer young children protection from being under the juvenile courts' jurisdiction.

1. Absolute Bar on Juvenile Jurisdiction.-Most states with minimum age laws have statutes that create an absolute bar to juvenile adjudication. ${ }^{96}$ This means if a child is under the statutory minimum age, that child cannot be charged and no rebuttable presumption is available. ${ }^{97}$ For example, Pennsylvania law states that in order for a child to be charged as a delinquent child, the child must be "ten years of age or older whom the court has found to have committed a delinquent act." ${ }^{98}$ Laws that statutorily define a lower minimum age provide for a simple determination on whether a child can be under the juvenile courts' jurisdiction, since age is the only determining factor.

2. Absolute Bar \& A Rebuttable Presumption.- Some states that have an absolute bar on jurisdiction based on a child's age also allow for an additional higher age range of children unable to be charged with a crime unless the court can show by clear and convincing evidence that the child had sufficient capacity to understand the act and knew it was wrong. ${ }^{99}$

For example, Washington's statute states "[c]hildren under the age of eight years are incapable of committing a crime." ${ }^{\prime 00}$ This sets an absolute bar for any child under the age of eight from being prosecuted. Additionally, Washington allows a rebuttable presumption to be used for those children between the ages of eight and twelve who commit a crime. ${ }^{101}$ Children in Washington between the ages of eight and twelve are presumed incapable of committing any crime, but the presumption may be rebutted in order for them to be charged with a crime if it can be established by clear and convincing evidence that the child had sufficient capacity to understand the act and know it was wrong. ${ }^{102}$

Nevada also has an absolute bar on punishment for any child under the age

GEN. STAT. § 7B-1501(7) (2018).

94. See Wash. Rev. Code § 9A.04.050 (2018); see Nev. Rev. Stat. Ann. § 194.010 (2018).

95. See Child in Need of Protection or Services, Minnesota Judicial Branch, http://www.mncourts.gov/Help-Topics/Child-in-Need-of-Protection-or-Services-(CHIPS).aspx [https://perma.cc/QJ98-ZVGD] (last visited Nov. 27, 2018); see LA. CHILD. CodE ANN. art. 804(3) (2018).

96. Minimum Age for Delinquency Adjudication-Multi-Jurisdiction Survey, supra note 2.

97. See 42 Pa. Cons. Stat. § 6302 (2018); Mass. Gen. Laws ch. 119, § 52 (2018); N.C. GEN. STAT. § 7B-1501(7) (2018).

98. 42 Pa. Cons. STAT. $§ 6302$ (2018).

99. See Wash. Rev. Code § 9A.04.050 (2018); see Nev. Rev. Stat. Ann. § 194.010 (2018).

100. WASH. REV. CODE § 9A.04.050 (2018).

101. State v. Erika D.W., 934 P.2d 704, 706 (Wash. Ct. App. 1997).

102. Id. 
of eight years old. ${ }^{103}$ Children cannot be charged with a crime if they are between eight and ten, unless they are charged with murder or a sexual offense. ${ }^{104}$ Additionally, a child cannot be charged with a crime if the child is "between the ages of 8 years and 14 years, in the absence of clear proof that at the time of committing the act charged against them they knew its wrongfulness." ${ }^{105}$ These statutes not only provide for a statutory minimum age, but also provide an additional age range of protection for older children if the court finds they lacked the mental capacity to know what they did was wrong at the time they committed the crime.

3. Holding Children Under the Minimum Age Responsible.- Some states do not have any repercussions for children under the statutory minimum age who commit delinquent acts or crimes. ${ }^{106}$ However, other states like Minnesota and Louisiana require children to be held accountable for their actions and receive services through programs outside of the juvenile justice system. ${ }^{107}$ Under Minnesota's Juvenile Court Act, a child under the age of ten cannot be a "delinquent child." 108 Minnesota's Child in Need of Protection or Services ("CHIPS") program requires a child who committed a delinquent act before ten years old to receive services through the program. ${ }^{109}$ Minnesota's legislators intend for children under ten to be removed from the juvenile justice system, so they are protected from the possibility of juvenile delinquency. ${ }^{110}$

Similar to Minnesota, in Louisiana, a delinquent act can only be committed by a child that is at least ten years old. ${ }^{111}$ When a child under ten is accused of an offense, the charge is processed as a Family in Need of Services ("FINS") case. ${ }^{112}$ These alternative approaches still hold children who have or are alleged to have committed a crime accountable for their actions by requiring them to get help and treatment, but not through the juvenile justice system. ${ }^{113}$

4. States Recently Setting a Minimum Age of Twelve.-In recent years, lawmakers in many states have introduced bills to either set a statutory minimum age or raise the current minimum age. ${ }^{114}$ In 2018, the Massachusetts legislature

103. Nev. Rev. Stat. Ann. § 194.010 (2018).

104. Id.

105. Id.

106. See generally Wash. Rev. Code § 9A.04.050 (2018); see Nev. Rev. Stat. Ann. § 194.010 (2018).

107. See Child in Need of Protection or Services, supra note 95; see LA. CHILD. CodE ANN. art. 804(3) (2018).

108. Matter of Welfare of S.A.C., 529 N.W.2d 517, 520 (Minn. Ct. App. 1995).

109. Child in Need of Protection or Services, supra note 95.

110. See Matter of Welfare of S.A.C., 529 N.W.2d at 519.

111. LA. Child. Code ANN. art. 804(3) (2018).

112. $I d$.

113. See Child in Need of Protection or Services, supra note 95.

114. See generally Juvenile Justice Bills Tracking Database, NATIONAL Conference of STATE LEGISLATORS, http://www.ncsl.org/research/civil-and-criminal-justice/ncsls-juvenile-justicebill-tracking-database.aspx [https://perma.cc/CLB6-LHXV] (last visited Feb. 4, 2019). 
amended its language defining who could be a delinquent child. ${ }^{115}$ Prior to 2018 , the youngest age at which a delinquent child could be adjudicated in Massachusetts was seven years old. ${ }^{116}$ Now, only a child between twelve and eighteen can be adjudicated as a delinquent. ${ }^{117}$

Before 2019, California had no minimum age limit at which children could be arrested, charged with a crime, or incarcerated. ${ }^{118}$ California's juvenile courts prosecuted children as young as five years old. ${ }^{119}$ In 2010, Santa Clara County, California adopted a twelve-and-over threshold for juvenile court adjudications. ${ }^{120}$ The county focuses on treating mental illness, trauma, and other underlying factors instead of exposing children to the juvenile justice system where underlying conditions typically go untreated. ${ }^{121}$

Due to great success stemming from Santa Clara County's juvenile justice system model, California Senators Holly Mitchell and Ricardo Lara introduced Senate Bill 439 on February 15, 2017, and it became law on January 1, 2019. ${ }^{122}$ This Bill established a minimum age of twelve before a child could be subject to the juvenile court's jurisdiction, except for in specific circumstances outlined by the statute. ${ }^{123}$ If a child under the minimum age of twelve draws the attention of law enforcement for an unlawful action, the county is "to release the minor to his or her parent, guardian, or caregiver." ${ }^{124}$ With the increasing amount of bills being introduced regarding juvenile jurisdiction and recent legislation passed in Massachusetts and California, it is likely other states will follow suit in the coming years. ${ }^{125}$

5. Other Countries' Minimum Age Requirements.-Most countries have

115. See MAss. GEN. LAws ch. 119, § 52 (2018).

116. State Profiles: Massachusetts, National Juvenile Defender Center, $\mathrm{http} / / /$ njdc.info/practice-policy-resources/state-profiles/massachusetts [https://perma.cc/W84WQUNW] (last visited Oct. 1, 2018).

117. MASS. GEN. LAWS ch. 119, § 52 (2018).

118. Times Editorial Board, How Young is Too Young for Jail? California Doesn't Have an Answer, But It Should, L.A. TIMES (Aug. 11, 2018), http://www.latimes.com/opinion/editorials/laed-minimum-age-jail-20180811-story.html [https://perma.cc/M8MC-34BA]; CAL. WELF. \& INST. CoDE $\S 602$ (2019).

119. Laura Garnette, Juvenile Court is No Place for Kids-California Must Set a Minimum Age, S.F. CHRONICLE (Aug. 13, 2018), https://www.sfchronicle.com/opinion/openforum/article/Juvenilecourt-is-no-place-for-kids-13153447.php [https://perma.cc/UCR3-E325].

120. Times Editorial Board, supra note 118.

121. Id.

122. Maureen Washburn, SB 439 Becomes Law, Ending the Prosecution of Children Under 12, Center on Juvenile and Criminal Justice (Oct. 23, 2018), http://www.cjcj.org/news/12289.; CAL. WeLF. \& InST. CODE $§ 602$ (West 2019).

123. CAL. Welf. \& Inst. Code $§ 602$ (West 2019).

124. Washburn, supra note 122.

125. See Several States Ponder Expansion of Juvenile Justice Beyond 18, The Chronicle (Mar. 11, 2019), https://chronicleofsocialchange.org/news-2/several-states-ponder-expansion-ofjuvenile-justice-beyond-18/34152 [https://perma.cc/993N-QJNG]. 
minimum age laws that offer children protections from their justice systems. ${ }^{126}$ In 1989, Article 40 of the United Nations Committee on Rights of the Child ("UNCRC") declared all nations set a minimum age of criminal responsibility, below which, no child may be subject to formal prosecution. ${ }^{127}$ The UNCRC recommended an "“absolute minimum' age of 12 for criminal responsibility" and has recently urged countries to raise ages even higher. ${ }^{128}$ The majority of Western European countries follow UNCRC's recommendation and set their minimum age of juvenile justice jurisdiction at age twelve or higher. ${ }^{29}$ Further, over thirty countries' minimum age of criminal responsibility is set at twelve, and over forty countries have a minimum age of criminal responsibility set at fourteen. ${ }^{130}$ The only member of the United Nations not to ratify the UNCRC is the United States. ${ }^{131}$ For the UNCRC to be ratified in the United States, it would take a two thirds majority vote in the Senate to pass. ${ }^{132}$ However, since 1995, several senators have continued to oppose Article 40 due to concerns over United States sovereignty. ${ }^{133}$

Even though the United States has not ratified Article 40 of the UNCRC, legislators and courts in the United States, including the United States Supreme Court, sometimes pay close attention to laws of other countries and international treaty opinions when deciding important issues. ${ }^{134}$ This thought process occasionally extends to cases involving juvenile rights. ${ }^{135}$ In Roper v. Simmons, the United States Supreme Court referred to foreign authorities as "instructive" when deciding that juveniles cannot be subject to execution. ${ }^{136}$ Justices John Paul Stevens, Sandra Day O'Connor, Anthony Kennedy, David Souter, Ruth Bader Ginsburg, and Steven Breyer have all expressed interest in utilizing foreign legal sources and international conventions to further United States laws, ${ }^{137}$ yet there

126. Economist Data Team, The Minimum Age of Criminal Responsibility Continues to Divide Opinion, The ECONOMist (Mar. 15, 2017), https://www.economist.com/graphic-detail/2017/ $03 / 15 /$ the-minimum-age-of-criminal-responsibility-continues-to-divide-opinion [https://perma.cc/VGK6-ENH6].

127. Barnert et al., supra note 1.

128. Economist Data Team, supra note 126.

129. Barnert et al., supra note 1.

130. Economist Data Team, supra note 126.

131. Barnert et al., supra note 1.

132. Karen Attiah, Why Won't the U.S. Ratify the U.N. 's Child Rights Treaty?, WASH. PosT (Nov. 21, 2014), https:/www.washingtonpost.com/blogs/post-partisan/wp/2014/11/21/why-wontthe-u-s-ratify-the-u-n-s-child-rights-treaty/?utm_term=.1a7b409aca83 [https://perma.cc/8JWNYZB9].

133. Id.

134. See Ernesto J. Sanchez, A Case Against Judicial Internationalism, 38 ConN. L. REV. 185, 187 (2005).

135. Id.

136. Roper v. Simmons, 543 U.S. 551, 575 (2005).

137. Sanchez, supra note 134 , at 186. 
is still no federal statute mandating a minimum age for juvenile jurisdiction. ${ }^{138}$ Because a federal minimum age law is unlikely in the foreseeable future, Indiana should take initiative and adopt a minimum age law.

All states recognize the need for protecting juveniles from the dangers of adult courts, ${ }^{139}$ and states are slowly recognizing that young children are vulnerable to the dangers of the juvenile justice system. ${ }^{140}$ Twenty-three states have laws protecting young children from the dangers of the juvenile justice system similar to many countries around the world with minimum age legislation. ${ }^{141}$ More states are proposing and passing legislation that establish or raise the current minimum age for juvenile jurisdiction. ${ }^{142}$ It is likely additional states will follow suit in the coming years.

\section{Why STATUTORY MinimUM AGE LAWS ARE NEEDED}

Statutory minimum age laws are needed to protect children from the juvenile justice system. Generally, the crimes children are committing are not serious, children often lack the mental capacity to make sound judgments, and most children who commit delinquent acts have underlying mental health disorders or substance abuse problems not being properly addressed. Further, minimum age laws will protect children from having an arrest or juvenile record which could negatively impact future schooling or employment.

\section{A. Not the Most Serious Offenders}

Just a small fraction of children under eighteen will ever come into contact with the juvenile justice system. ${ }^{143}$ Of that small fraction, most crimes committed by children under twelve are non-violent offenses, such as property crimes or theft, that do not pose a great danger to the general public. ${ }^{144}$ Between 1980 and 2008 , children under the age of fourteen made up less than 0.5 percent of total homicide offenders, whereas teenagers between the ages of fourteen and

138. Barnert et al., supra note 1.

139. See Zang, supra note 78 (explaining that "[p]rotecting juveniles from the consequences of an adult criminal record and separating incarcerated juveniles from the influence of adult criminals were main reasons for the establishment of juvenile courts.").

140. See generally Minimum Age for Delinquency Adjudication-Multi-Jurisdiction Survey, supra note 2 (showing that all but five of the statutes of twenty-three U.S. states and territories specifying a minimum age for delinquency adjudication were passed between 2015 and present).

141. Id.; Economist Data Team, supra note 126.

142. See, e.g., H.R. 1242, 121st Gen. Assemb., Reg. Sess. (Ind. 2019).; see generally Juvenile Justice Bills Tracking Database, supra note 114 (providing database access to a listing of states that have pending juvenile justice reform).

143. See Juvenile Incarceration, CHILD TRENDS, https://www.childtrends.org/indicators/ juvenile-detention [https://perma.cc/3UCV-YTNR] (last visited Nov. 10, 2018).

144. Juvenile Offenders and Victims: 2014 National Report, NAT'L CTR. FOR JUVENILE JustiCE 160-61 (Dec. 2014), https://www.ojjdp.gov/ojstatbb/nr2014/downloads/NR2014.pdf [https://perma.cc/M6GJ-YHGT]. 
seventeen made up 10.6 percent of the total amount of homicide offenders. ${ }^{145}$ Generally, children do not pose a great danger to public safety; violent crimes are least likely for a child under twelve to commit. ${ }^{146}$

Even though violence in schools, including school shootings, have increased in past decades, most of these violent acts are being committed by either adolescents or adults and not children under ten. ${ }^{147}$ By far the great majority of crimes young children commit are very minor and rarely threaten public safety or endanger lives. ${ }^{148}$

\section{B. Underlying Issues in Children Not Being Addressed}

Children with underlying mental health disorders and children dealing with substance abuse problems have little chance of receiving an accurate assessment or appropriate treatment while in the juvenile justice system. ${ }^{149}$

Children who are arrested or charged in the juvenile justice system are significantly more likely to have histories of maltreatment, learning disorders, or underlying behavioral health problems. ${ }^{150}$ Up to 90 percent of children in the juvenile justice system have experienced some type of traumatic event in their life, and 62 percent of those children experienced that traumatic event within the first five years of their life. ${ }^{151}$ Moreover, 70 percent of children in the juvenile justice system met the criteria for a mental health disorder and approximately 30 percent of them meet the criteria for Post-traumatic Stress Disorder ("PTSD"). ${ }^{152}$ Many of these mental health disorders are going unaddressed which could lead to more significant issues, including suicide, if they are not properly addressed. ${ }^{153}$ Juveniles who are in custody of the juvenile justice system are four times more likely to commit suicide than those who are not. ${ }^{154}$ Further, lack of adequate

145. Alexia Cooper \& Erica L. Smith, Homicide Trends in the United States 1980-2008, U.S. DEP'T OF JUSTICE 3 (Nov. 2011), https:/www.bjs.gov/content/pub/pdf/htus8008.pdf [https://perma. cc/3QPB-HFH7].

146. Id.

147. See Bonnie Berkowitz et al., The Terrible Numbers That Grow with Each Mass Shooting, ThE WASH. Post, https://www.washingtonpost.com/graphics/2018/national/mass-shootings-inamerica/?utm_term=.c2ae13881fdd [https://perma.cc/YW8G-4ZA9] (last updated Nov. 8. 2018).

148. Juvenile Offenders and Victims: 2014 National Report, supra note 144.

149. JoAn McCord et Al., Juvenile Crime, Juvenile Justice 191 (2001).

150. Barnert et al., supra note 1 .

151. Carley B. Dierkhising et al., Trauma Histories among Justice-Involved Youth: Findings from the National Child Traumatic Stress Network, EuRoPEAN J. OF PSYCHOTRAUMATOLOGY (July 16, 2013), http://doi.org/10.3402/ejpt.v4i0.20274 [https://perma.cc/AA8D-4H7P].

152. Id.

153. Juvenile Justice, NAT'L Alliance On Mental Illness, https://www.nami.org/LearnMore/Mental-Health-Public-Policy/Juvenile-Justice [https://perma.cc/NZ5G-ZL6Y] (last visited Feb. 4, 2019).

154. Id. 
treatment increases the likelihood of re-arrest upon exiting the system. ${ }^{155}$

In addition to mental health disorders being a major concern, 78.4 percent of juveniles who are taken into custody suffer from substance abuse. ${ }^{156}$ In $2000,1.9$ million of the 2.4 million juveniles arrested in the country had substance abuse or addiction problems, yet only 68,600 received treatment. ${ }^{157}$ In recent years, juvenile justice systems have increased the number of substance abuse programs to keep up with the demand of juveniles needing assistance, however, it is still not enough to keep up with the growing drug epidemic in the United States. ${ }^{158}$ A statutory minimum age will allow children the opportunity to get quicker, more specialized, private treatment by not having to spend time going through the juvenile justice system where their individual needs may not be met.

\section{Brain Development}

Children under the age of twelve often lack the mental capability to make sound judgments and fully understand the consequences of their actions. ${ }^{159}$ Medical advances allow doctors and scientists to distinctly see how the human brain develops. ${ }^{160}$ Scientific findings have consistently affirmed that children under twelve are not fully mature in their judgment, problem solving, or decision making. ${ }^{161}$ Children's most rapid growth and development occurs during puberty. ${ }^{162}$ Puberty typically starts between the ages of eleven to fourteen for males and nine to twelve for females. ${ }^{163}$ Puberty generally lasts anywhere from two to five years in both males and females. ${ }^{164}$ The prefrontal cortex, which

155. Id.

156. Criminal Neglect: Substance Abuse, Juvenile Justice and The Children Left Behind, CTR. ON ADDICTION (Oct. 2004), https://www.centeronaddiction.org/addiction-research/reports/criminalneglect-substance-abuse-juvenile-justice-and-children-left [https://perma.cc/2XY5-S278].

157. Id.

158. See generally Model Policies for Juvenile Justice and Substance Abuse Treatment, RECLAIMING FUtURES (2008), http://www.njjn.org/uploads/digital-library/resource_860.pdf [https://perma.cc/J4TX-AFSM].

159. See generally What are the Implications of Adolescent Brain Development for Juvenile Justice?, COAL. FOR JUVENILE JustiCE (2006), https://www.juvjustice.org/sites/default/files/ resource-files/resource_134.pdf [https://perma.cc/YN3B-EZY5].

160. See generally id.

161. See generallyid.

162. See generally id. at 1 .

163. See generally Barbara Huberman, Growth and Development, Ages Nine to Twelve-What Parents Need to Know, ADVOCATES FOR YOUTH, http://www.advocatesforyouth.org/publications/ 155-parents [https://perma.cc/FBH9-7EMJ] (last visited Oct. 12, 2018).

164. See generally Puberty: Normal Growth and Development in Boys, FAIRVIEw, https://www.fairview.org/sitecore/content/Fairview/Home/Patient-Education/Articles/English/p/u/b/ e/r/Puberty_Normal_Growth_and_Development_in_Boys_89559 [https://perma.cc/HC85-CZMR] (last visited Feb. 4, 2019); see generally Puberty: Normal Growth and Development in Girls, FAIRVIEw, https://www.fairview.org/sitecore/content/Fairview/Home/Patient-Education/Articles/ 
governs a person's reasoning, thought, and impulse control, is the final part of the human brain to mature. ${ }^{165}$ The human brain develops slowly and does not finish developing until around the age of twenty-five. ${ }^{166}$ Due to their underdeveloped brains, children under twelve often lack the ability to make sound judgments. ${ }^{167}$

The United States Supreme Court decided several important juvenile related cases on the premise that adolescent brains are not as developed as adult brains and therefore renders them less blameworthy for the crime. ${ }^{168}$ Specifically, in Roper v. Simmons, the Court confirmed scientific studies showing that "[a] lack of maturity and an underdeveloped sense of responsibility are found in youth more often than in adults and are more understandable among the youth," and that "[t]hese qualities often result in impetuous and ill-considered actions and decisions." ${ }^{169}$ Cases like Roper, where the juvenile was seventeen, focus on brain development of juveniles in their teens, but fail to discuss how those children who have not reached puberty or are going through puberty are even less developed and should be allowed more protections. ${ }^{170}$ Due to rapid brain development occurring during and after puberty, children under twelve are likely to have even greater limitations on understanding the full impact of their actions. ${ }^{171}$

\section{Costs of Children Entering the System}

When a child enters the juvenile justice system, great costs are imposed on both the child's family and the state. ${ }^{172}$ Families of children in juvenile facilities are often faced with the burden of having to take on debt. ${ }^{173}$ The state is also burdened with housing and other court related costs. ${ }^{174}$

The majority of children in the juvenile justice system come from poor families where poverty is prevalent. ${ }^{175}$ Juvenile court costs place burdens on

English/p/u/b/e/r/Puberty_Normal_Growth_and_Development_in_Girls_89561 [https:// perma.cc/PG7D-FBLF] (last visited Feb. 4, 2019).

165. See generally Stephanie Tabashneck, "Raise the Age” Legislation: Developmentally Tailored Justice, 32 CRIM. Just. 13, 16 (2018).

166. See generally What are the Implications of Adolescent Brain Development for Juvenile Justice?, supra note 159.

167. See generally id.

168. Barnert et al., supra note 1.

169. Roper, 543 U.S. at 569 (quoting Johnson v. Texas, 509 U.S. 350, 367 (1993)).

170. See Tabashneck, supra note 165.

171. What are the Implications of Adolescent Brain Development for Juvenile Justice?, supra note 159.

172. Jessica Feierman et al., Debtors' Prison for Kids? The High Cost of Fines and Fees in the Juvenile Justice System, JuvENILE LAW CTR. (2016), http://debtorsprison.jlc.org/documents/jlcdebtors-prison.pdf [https://perma.cc/E2GM-BZFT].

173. Id.

174. See Per Diem Report, Juvenile Facilities, IND. D.O.C. (2016), available at https://www.in.gov/idoc/files/FY16\%20Per\%20Diem.pdf [https://perma.cc/Y6RA-HD69].

175. Peter M. Cicchino, The Problem Child: An Empirical Survey and Rhetorical Analysis of 
families who struggle daily with trying to come up with enough money to pay for housing or food. ${ }^{176}$ Indiana mandates that families pay all court costs involving their child's juvenile proceeding. ${ }^{177}$ If a party fails to pay any costs or fees associated with the court, the court may find them in contempt, and a judgment may be issued on the outstanding amount. ${ }^{178}$ Further, it is mandatory for parents to pay supervision costs and diversion fees for their child. ${ }^{179}$ However, the courts are allowed discretion in determining whether the parents should pay probation costs. ${ }^{180}$ Since many families often lack the resources to pay for the expensive costs associated with the juvenile justice system, their children are forced to stay in placements or detention longer than they should, and the cases take longer to close. ${ }^{181}$ Additionally, if parents are not able to pay costs, they may be subject to civil penalties. ${ }^{182}$

Family debt is often further increased due to courts assigning more fees to parents of young children. Because of this, less money is able to be used for health services, medical services, or educational opportunities. ${ }^{183}$ When a child's family encounters financial struggles, the child may be enticed to commit thefts and petty crimes to help their family make ends meet, continuing the cycle. ${ }^{184}$

Further, placing children in the juvenile justice system places a burden on taxpayers and the state. ${ }^{185}$ There are costs imposed on the state during all stages of the juvenile process, including when a juvenile is sentenced to a department of corrections facility. ${ }^{186}$ In the 2016 fiscal year, Indiana incurred $\$ 41,156,094.00$ in total operating expenses for only four of their juvenile facilities: Camp Summit, Madison Juvenile Facility, North Central Juvenile Facility, and Pendleton Juvenile Facility. ${ }^{187}$ The total average daily population for these four facilities is 453 juveniles, which causes the average cost to be $\$ 249.08$ per day per juvenile. ${ }^{188}$

In 2006, Indiana joined the Annie E. Casey Foundation's Juvenile Detention Alternatives Initiative ("JDAI") program. ${ }^{189}$ Children placed in detention centers

Child Poverty in the United States, 5 J.L. \& PoL'y 5, 28-29 (1996).

176. See id.

177. Feierman et al., supra note 172, at 17.

178. Id. at 7.

179. Id. at 11,13 .

180. Id. at 11 .

181. Id. at 15,24 .

182. Id. at 12 .

183. See Andrea Cuentas, Poverty: Key Factors Contributing to High Delinquency Rates, Medium (May 3, 2018), https://medium.com/soci100wsp18/poverty-key-factors-contributing-tohigh-juvenile-delinquency-rates-31f9aebc44e8 [https://perma.cc/9D58-E4U4].

184. See Cicchino, supra note 175.

185. See Per Diem Report, supra note 174.

186. Id.

187. Id.

188. Id.

189. Juvenile Detention Alternatives Initiative, IND. Div. OF Youth SERvs., https://www.in. 
pending court hearings further impose costs on taxpayers and the state, which is why programs like JDAI are necessary. ${ }^{190}$ This program allows children to be placed in community-based alternative programs, instead of secure detention facilities. ${ }^{191}$ Since its inception, thirty-one counties in Indiana have adopted programs such as JDAI to reduce reliance on local confinement of court-involved youth. ${ }^{192}$ Indiana's JDAI core principle is that "[a]11 youth involved in the juvenile justice system have opportunities to develop into healthy, productive adults."193 Marion County, which joined the JDAI in 2006, has reduced detention admissions by 66.4 percent and the average daily population in juvenile detention centers by 40.8 percent. ${ }^{194}$ The downward trend of children in secured facilities is not only happening in Marion County, but in all Indiana counties with JDAI. ${ }^{195}$ In 2016 there was a 53-percent reduction rate of juvenile admission and a 47percent decline in juvenile felony petitions filed statewide. ${ }^{196}$ JDAI not only saves the state and taxpayers money by reducing the number of juveniles in secured facilities, ${ }^{197}$ it increases the juveniles chances of being a successful member of the community. ${ }^{198}$ However, only thirty-one of the ninety-two counties in Indiana so far have JDAI programs in place. ${ }^{199}$

\section{E. A System Lacking Uniformity}

Indiana's juvenile justice system has many stages, and they all involve discretion. ${ }^{200}$ Wide latitude of discretion is one of the great benefits of the juvenile

gov/idoc/dys/2407.htm [https://perma.cc/6GJK-SBZD] (last visited Nov. 12, 2018).

190. Id.

191. Richard A. Mendel, Juvenile Detention Alternatives Initiative Progress Report 2014, THE ANNIE E. CASEY Found. (2014), https://www.aecf.org/m/resourcedoc/aecf-2014JDAIProgress Report-2014.pdf\#page $=15$ [https://perma.cc/3RLZ-LM22].

192. Juvenile Detention Alternatives Initiative, supra note 189.

193. Ind. Juvenile Det. Alts. Initiative, IndianA’s JDAi CORE PrinciPles, https://www. in.gov/judiciary/iocs/files/jdai-core-principles.pdf [https://perma.cc/6ZDN-P34W] (last visited Nov. 13, 2018).

194. Juvenile Detention Alternatives Initiative, supra note 189.

195. Id.

196. Id.

197. See Indiana Juvenile Detention Alternatives Initiative, supra note 189 ("JDAI is based on the belief that it is in the best interest of youth and the community to provide community-based alternative programs which allow youth to remain in the community while still ensuring public safety.").

198. Id.

199. Id.

200. See Elizabeth Gladden Kehoe \& Kim Brooks Tandy, Indiana: An Assessment of Access to Counsel \& Quality of Representation in Delinquency Proceedings 24-28 (2006), http://njdc.info/wp-content/uploads/2013/11/Final-Indiana-Assessment.pdf [https://perma. cc/VT6P-V55L]. 
justice system and distinguishes it from the adult system. ${ }^{201}$ While both systems allow for discretion throughout, the biggest difference between these systems comes when the juvenile judge can decide whether the child should be charged or whether there are other steps that can be taken. ${ }^{202}$ Discretion in the juvenile justice system first starts with the officer who investigates the incident. ${ }^{203}$ If the investigating officer has probable cause to believe a delinquent act has occurred, the officer has the discretion to decide whether to take the child into custody or whether to release the child to his parents with a written promise to appear in court. ${ }^{204}$ Next, the probation and intake officers will review the police officer's decision and then have the power to release or detain the child. ${ }^{205}$ At the detention hearing, the judge is allowed a high degree of discretion to release the child or continue to detain him or her. ${ }^{206}$ The prosecuting attorney can dismiss the case or charge the child with a crime. ${ }^{207}$ At disposition, the judge takes into account all the information and has discretion on which course of action is the best for the child. ${ }^{208}$

However, there are downsides to discretion. Each stage of the juvenile process gives discretionary authority to key individuals in the process - police officers, intake officers, and prosecutors ${ }^{209}$ — which leads to a lack of uniformity for young children being arrested or charged with a crime. Each figure in the process may have different ideas, beliefs, or thoughts on what should happen to young children in the system, which is why a bright line rule leading to uniformity here would be best. ${ }^{210}$ While it could be argued that discretion allows for a child to have individualized attention, it is more important to eliminate the possibilities of abuse in the system when children are involved.

With more discretion there is a higher chance of abuse. ${ }^{211}$ Many figures throughout the process are able to decide whether the child will be charged or not, whether the child should be given an informal adjustment, or what the child's punishment should be. ${ }^{212}$ Factors that could, but should not, play a role in what happens to a juvenile at each stage in the system include community pressures, race of the child, and personal and political factors. ${ }^{213}$ Because of these

201. See id. at 23-24.

202. See id. at 26.

203. See id.

204. Id. at 24 .

205. Id.

206. See id.

207. Id. at 25 .

208. Id. at 26.

209. See id. at 24-27.

210. See id.

211. See generally id.

212. Brenda Gordon, A Criminal's Justice or a Childs Injustice? Trends in the Waiver of Juvenile Court Jurisdiction and the Flaws in the Arizona Response, 41 ARIZ. L. REV. 193, 224-25 (1999).

213. See generally Bennett L. Gershman, Prosecutorial Decisionmaking and Discretion in the 
discretionary factors, a child could receive a different outcome for the same crime, depending on the county. ${ }^{214}$

Further, the juvenile justice system lacks uniformity in the programs available to juveniles from county to county. ${ }^{215}$ Programs such as JDAI are not offered in all Indiana counties. ${ }^{216}$ A statutory minimum age would further protect young children from the unpredictability of the juvenile justice system.

\section{F. The Increasing Permanency and Access to Juvenile Records}

Up until the 1960s, confidentiality was an integral part of the juvenile justice system model. ${ }^{217}$ This was to protect the juvenile from the public and prevent the juvenile from developing a bad self-image, which decreases the likelihood of successful rehabilitation. ${ }^{218}$ In In re Gault, the Supreme Court recognized that "[t]he policy of the juvenile law is to hide youthful errors from the full gaze of the public and bury them in the graveyard of the forgotten past." ${ }^{219}$ However, the Court admitted this "claim of secrecy . . is more rhetoric than reality." 220

In the 1980s and 1990s, greater media interest in juvenile records and information-sharing began to erode confidentiality protections. ${ }^{21}$ This led to laws allowing certain juvenile information to become public. ${ }^{22}$ It is a common misconception that juvenile records are sealed and unavailable to the general public. ${ }^{223}$ Another misconception is that once juveniles turn eighteen years old, their juvenile records are erased through expungement. ${ }^{224}$ In most states, juvenile records are not automatically expunged when a person turns eighteen; the court must be petitioned to expunge the records. ${ }^{225}$ In Indiana, the records may either be sealed or destroyed in accordance with Indiana Code section 31-39-8, which places the burden on the juvenile to file a petition with the court to get the record expunged. ${ }^{226}$ The juvenile court judge then has the discretion to grant or deny the expungement. ${ }^{27}$ This discretion causes inconsistencies from case to case and can

Charging Function, 62 HASTINGS L.J. 1259, 1276-78 (2011).

214. See id.

215. See Juvenile Detention Alternatives Initiative, supra note 189.

216. Id.

217. Butts \& Mitchell, supra note 49, at 190.

218. Id.

219. In re Gault, 387 U.S. 3, 32 (1967) (quoting In re Gault, 407 P.2d 760, 767 (Ariz. 1965)).

220. Id. at 24 .

221. Butts \& Mitchell, supra note 49, at 190.

222. Id.

223. Joy Radice, The Juvenile Record Myth, 106 GEO. L.J. 365, 383 (2018).

224. Id.

225. Id. at 375 .

226. Ind. CodE § 31-39-8 (2019); Ind. Pub. Def. Counsel, How to Expunge your Juvenile Records, IN.GOV, https://www.in.gov/ipdc/public/2654.htm [https://perma.cc/3AML-GP2B] (last visited Oct. 10, 2018).

227. Ind. Pub. Def. Counsel, supra note 226. 
affect the child later in life.

\section{G. Juvenile Records Impact Later in Life: Collateral Consequences}

Not only are juvenile records not always private, the records can negatively impact the child later in life, even after expungement. ${ }^{228}$ Juvenile records from when a child was in elementary school could impact their chances to enter college or receive financial aid. ${ }^{229}$ In recent years, some colleges have backed away from asking questions about whether a person has been arrested or committed a juvenile offense in their applications, but there are still many institutions that ask about arrests and other offenses, including juvenile arrests or delinquency offenses. ${ }^{230}$

Juvenile records may also negatively impact students' financial aid eligibility. ${ }^{231}$ This could drastically change the future for a child who could not otherwise afford to go to college. ${ }^{232}$ Indiana passed legislation in 1991 creating the 21st Century Scholarship program that fully funds scholarships to low income high school students entering college. ${ }^{233}$ More than 110,000 Hoosiers are enrolled in the program today, and at least 30,000 low income Hoosiers have earned a degree with a 21 st Century Scholarship. ${ }^{234}$ This program has earned a nationwide reputation for a model program for other states. ${ }^{235}$ However, for an Indiana student to qualify for a 21 st Century Scholarship, they must certify in writing that before their graduation from high school, they have not committed a crime or delinquent act. ${ }^{236}$ This could be any type of delinquent act committed by the child at any age - even acts committed while in elementary school. ${ }^{237}$

A juvenile history can negatively impact adult employment. ${ }^{238}$ In recent years, many states have adopted "Ban the Box" laws that prohibit employers from

228. See Radice, supra note 223 , at 375.

229. See $i d$. at 387.

230. Stephanie Saul, Colleges That Ask Applicants About Brushes with the Law Draw Scrutiny, N.Y. TIMES (Jan. 28, 2016), https://www.nytimes.com/2016/01/29/us/colleges-that-askapplicants-about-brushes-with-the-law-draw-scrutiny.html [https://perma.cc/7CFR-ZK5Q].

231. See, e.g., IND. CoDE $\S 21-12-6-6(a)(5)$ (2018).

232. See generally, 21st Century Scholars 25 Years of Supporting Student Success, IND. COMM'N FOR Higher EDUC., available at https:/www.in.gov/che/files/25th_Anniversary_ Brochure_11-18-15_Final_pages.pdf [https://perma.cc/44JY-4WTY].

233. Id. at 3 .

234. Id. at 5 .

235. Id. at 9 .

236. IND. CODE § 21-12-6-6(a)(5) (2018).

237. See id.

238. Radice, supra note 223, at 387; see Jeff Parrott, Indiana First State to Scrap Local "Ban the Box" Laws, South Bend TRIB. (July 2, 2017), https://www.southbendtribune.com/news/ local/indiana-first-state-to-scrap-local-ban-the-box-laws/article_c1a31101-db3e-5d10-aae1407396f1948e.html [https://perma.cc/S24W-ZZL6]. 
asking about a job applicants' criminal history on applications. ${ }^{239}$ However, Indiana is the first state to ban "ban the box" laws and instead protect employers" right to ask about a job applicant's criminal history on job applications. ${ }^{240}$ Many applications ask, "Have you ever been arrested?" This simple inquiry can lead to further questions about a juvenile record and can eventually lead to a denial of a job for an offense committed as a child. ${ }^{241}$

Juvenile records may also play a factor in sentencing decisions when a person commits a crime as an adult. ${ }^{242}$ Judges in Indiana are given the ability to consider aggravating circumstances when deciding a person's sentence. ${ }^{243}$ One of the factors a judge may consider when deciding on whether a person will receive a longer sentence is if the person has a history of criminal or delinquent behavior. ${ }^{244}$

Juvenile arrests or delinquency records have harmful effects that could limit the success of someone's entire life by preventing them from attending and paying for a college of their dreams, or preventing them from getting a wellpaying job to support their families all because of something they did while in elementary school. ${ }^{245}$

\section{H. Competency is Too Low of a Bar}

Juveniles may use a lack of competency defense, but only after the child has already had contact with the juvenile justice system. ${ }^{246}$ By the time the child is able to assert a defense, the child may have already been through several stages of the juvenile justice system, and often, the harm has already been done. ${ }^{247}$

The United States Supreme Court first addressed the competency defense in Dusky v. United States, where the Court held that one must be found competent to stand trial. ${ }^{248}$ Chief Justice Warren Burger stated in Drope v. Missouri, "[i]t has long been accepted that a person whose mental condition is such that he lacks the capacity to understand the nature and object of the proceedings against him, to consult with counsel, and to assist in preparing his defense may not be subjected to a trial. ${ }^{249}$ However, these cases were based on adult defendants and did not address the issue of whether these rights would extend to juveniles in the juvenile justice system. ${ }^{250}$

239. E.g., Parrott, supra note 238.

240. Id.

241. See Radice, supra note 223 , at 387.

242. Id. at 388 .

243. IND. CODE $§ 35-38-1-7.1$ (2018).

244. Id. § 35-28-1-7.1(a)(2) (2018).

245. See Radice, supra note 223, at 365, 387; see also 21st Century Scholars 25 Years of Supporting Student Success, supra note 232, at 9; see also Parrott, supra note 238.

246. See Kenoe \& TANDy, supra note 200, at 35-36, 45-46.

247. Id.; see, e.g., In re K.G., 808 N.E.2d 631, 632 (Ind. 2004).

248. Dusky v. United States, 362 U.S. 402 (1960).

249. Drope v. Missouri, 420 U.S. 162, 171 (1975).

250. See id.; see also Dusky, 362 U.S. at 402. 
Currently, Indiana's Juvenile Code does not contain competency procedures to protect children; however, twenty-one other states, including neighboring states Ohio and Michigan, do provide such statutory protections. ${ }^{251}$ The Indiana Supreme Court has read into Indiana Code section 31-32-12-1 that the court may order an "examination and/or treatment of a child after a delinquency petition has been filed in order to determine the child's competency." 252 The Indiana Supreme Court held in In re K.G. that "juveniles alleged to be delinquent have the constitutional right to have their competency determined before they are subjected to delinquency proceedings, [and] the adult competency statute is not applicable in reaching that determination." 253 Therefore, children must be competent to stand trial, and a lack of competency defense may be used.

Competency proceedings offer some protections for children who are too young to understand the proceedings or unable to assist their attorney. However, juveniles are still left vulnerable. ${ }^{254}$ There are several steps a child must go through in Indiana's juvenile court system before a competency defense can be used. ${ }^{255} \mathrm{~A}$ child could be arrested or held for several weeks in a detention facility before being able to assert a defense. ${ }^{256}$ Additionally, competency proceedings are very difficult to assess. ${ }^{257}$ Even though competency defenses do offer some protections for children, often children have already spent a considerable amount of time in the juvenile justice system before these defenses could come into play. ${ }^{258}$ During this time, efforts and costs could be better spent on treatment and programs to address the underlying issues.

\section{RECOMMENDATIONS}

In 2019, House Bill 1242 was introduced by Representative Cherrish Pryor. ${ }^{259}$ This Bill would set a minimum age for juvenile detention in Indiana. ${ }^{260}$ It provides that "a child who is less than twelve years of age may not be held in a juvenile detention facility" unless the child is either ten or eleven; the court finds there is probable cause they committed murder; and it is in the best interest of the

251. Juvenile Justice: States with Juvenile Competency Laws, NAT'L Conf. OF ST. Legislatures (May 1, 2018), http://www.ncsl.org/research/civil-and-criminal-justice/states-withjuvenile-competency-laws.aspx [https://perma.cc/F6AZ-Y6A8].

252. In re K.G., 808 N.E. $2 \mathrm{~d}$ at 639.

253. Id. at 632 .

254. See Kehoe \& Tandy, supra note 200, at 74-75.

255. See id. at 35-37.

256. See id. at 26.

257. Competency to Stand Trial in Juvenile Court: Recommendations for Policymakers, NAt'L. Juvenile Justice Network (Nov. 2012), http:/www.njjn.org/uploads/digital-library/ NJJN_MfC_Juvenile-Competency-to-Stand-Trial_FINAL-Nov2012.pdf [https://perma.cc/4TEEM44E].

258. Kehoe \& Tandy, supra note 200, at 24-26.

259. H.B. 1242, 121st Gen. Assemb., 1st Reg. Sess. (Ind. 2019).

260. Id. 
child or community they be placed in detention. ${ }^{261}$ The court must first make specified written findings and conclusions to order a ten- or eleven-year-old to be sent to juvenile detention. ${ }^{262}$

This proposed legislation is a step in the right direction but still leaves young children in the potential dangers of the juvenile justice system even if they avoid detention. ${ }^{263}$ Children under the age of twelve generally only commit minor nonviolent offenses that do not pose a great threat to the public. ${ }^{264}$ Children who commit crimes generally have underlying issues that need addressed and do not have the mental capability to fully understand their actions. ${ }^{265}$ Further, due to a great amount of discretion in the juvenile justice system, young children are left most susceptible to the dangers of the system. ${ }^{266}$ Because of this, Indiana should follow suit with the twenty-one other states that have passed minimum age legislation for juvenile court jurisdiction.

\section{A. Establish a Defined Statutory Minimum Age}

Indiana should adopt a statutory minimum age of twelve to clearly establish the age for the juvenile courts to have jurisdiction. However, if a child is charged with a sexual ${ }^{267}$ or violent ${ }^{268}$ act, then the age of jurisdiction would be lowered to ten. Further, if the act was sexual or violent, that child could be detained for up to twenty-four hours before being released to a parent or treatment facility. This is in line with recent trends by states that have passed minimum age legislation establishing juvenile jurisdiction at twelve. ${ }^{269}$ Further, Indiana would join the twenty-one other states that currently have legislation on the books and align itself with the growing global trend of offering more protections to children. ${ }^{270}$

\section{B. Expand Indiana CHINS}

In Indiana, a CHINS proceeding is for "a child under the age of eighteen who is neglected or abused, AND who is not getting [the] care or treatment [they] need." ${ }^{271}$ CHINS proceedings "are not criminal proceedings" and are meant to

261. Id.

262. Id.

263. Id.

264. Juvenile Offenders and Victims: 2014 National Report, supra note 144, at 138-39.

265. What are the Implications of Adolescent Brain Development for Juvenile Justice?, supra note 159 , at 1 .

266. See Kehoe \& Tandy, supra note 200 , at 24-28.

267. IND. CODE $\S \S 35-42-4-1$ to -8 (2019).

268. IND. CODE $\S 5-2-6.1-8$ (2019).

269. E.g., Mass. Gen. Laws ch. 119, § 52 (2019); E.g., Cal. Welf. \& Inst. Code $\S 602$ (2019).

270. Minimum Age for Delinquency Adjudication- Multi-Jurisdiction Survey, supra note 2; The Minimum Age of Criminal Responsibility Continues to Divide Opinion, supra note 126.

271. General Information About CHINS, Ind. Legal Services, InC., https://www. indianalegalservices.org/node/56/general-information-about-chins [https://perma.cc/CEW8-RAG2] 
"protect and care for the child." ${ }^{272}$ If a CHINS case is filed against a parent, there is an initial hearing, followed by a fact-finding hearing, then a disposition hearing. ${ }^{273}$ At the disposition hearing, "the court decides what orders should be made regarding the child's placement" and what services the child and parent should require. ${ }^{274}$ The court has many options available to use during the disposition hearing. ${ }^{275}$ It can order supervision of the child or outpatient treatment for the child; place the child in a therapeutic placement; or order other programs that will benefit the child. ${ }^{276}$

Unlike Minnesota and Louisiana's state programs, which extend to include children who commit offenses but have not yet reached the age of juvenile court jurisdiction, ${ }^{277}$ Indiana's CHINS program does not extend to provide services for children who commit delinquent acts or status offenses. ${ }^{278}$ Minnesota's CHIPS program allows children who commit delinquencies under the age of ten to be processed as a CHIPS case instead of a juvenile case. ${ }^{279}$ Louisiana's FINS program "works with youth and their families."280 Grounds for a FINS adjudication include truancy, disobeying parents, runaway behavior, or violation of law by a child under the age of ten. ${ }^{281}$

In addition to establishing a minimum age for juvenile court jurisdiction, Indiana should expand its CHINS program to include children who commit delinquent acts and who are under the age of the juvenile courts' jurisdiction. This allows for a child to be accountable for their actions and get the help and treatment they need. An extended CHINS program would further protect children from the juvenile justice system and give the child the best chance to rehabilitate and live a productive life.

\section{CONCLUSION}

Courts and legislators have long recognized the need to protect juveniles from adult courts by setting upper age limits for juvenile court jurisdiction. ${ }^{282}$ Since the

(last visited Nov. 12, 2018).

272. Id.

273. Id.

274. Id.

275. Id.

276. Id.

277. Child in Need of Protection or Services (CHIPS), supra note 95; LA. CHILD. CODE ANN. art. 804(3) (2018).

278. See General Information About CHINS, supra note 271 (listing the reasons a child can be in CHINS).

279. See Child in Need of Protection or Services (CHIPS), supra note 95.

280. The Juvenile Justice Process, St. of LA. Off. Of Juvenile Justice, https://ojj.la.gov/ policies-systems/the-juvenile-justice-process/ [https://perma.cc/BP6L-GXFP] (last visited Nov. 12, 2018).

281. Id.

282. See Zang, supra note 78. 
first juvenile court was established almost 120 years ago, there has been a dramatic change in the philosophy of the juvenile justice system. ${ }^{283}$ The juvenile justice system was once very informal where rehabilitation and the child's best interest were the top priorities. ${ }^{284}$ Abuses to the system in the 1950s led to a series of United States Supreme Court decisions that further blurred the lines between juvenile and adult courts. ${ }^{285}$ Courts and legislators often forget that juvenile courts now resemble adult courts more than ever, and most juvenile courts do not have a lower age limit. ${ }^{286}$ Indiana should join the twenty-one other states as well as other countries by enacting legislation to further protect children from the dangers of the juvenile justice system.

283. See Juvenile Justice History, supra note 38.

284. Sullivan, supra note 4, at 282.

285. Juvenile Justice History, supra note 38.

286. Minimum Age for Delinquency Adjudication-Multi-Jurisdiction Survey, supra note 2. 